\title{
KAJIAN MUTU IKAN TUNA (Thunnus albacares) SEGAR DI PASAR BERSEHATI KELURAHAN CALACA MANADO
}

\author{
Ade Neni Laismina, Lita A.D.Y Montolalu, Feny Mentang
}

Fakultas Perikanan dan Ilmu Kelautan, Universitas Sam Ratulangi, Manado, Sulawesi Utara.

\begin{abstract}
The purpose of this study was to determine the quality of tuna ( Thunnus albacares ) Fresh on the market Bersehati with testing TVB - N, pH , and organoleptic test by sampling time and different merchants. The method used is descriptive exploratory method, which collects data already available facts and observations in the field through pancatatan in detail and then systematically analyzed data based on quantitative and qualitative data. The results obtained by the average value of TVB-N in the Tuna (Thunnus albacares) ranged from $8.96 \mathrm{mg} \mathrm{N} / 100 \mathrm{~g}$ sample to $10.92 \mathrm{mg} \mathrm{N} / 100 \mathrm{~g}$ sample of the sampling clock 06:00 to 7:00. The average value of TVB - N sampling clock 12:00 to 13:00 ranged between $12.16 \mathrm{mg} \mathrm{N} / 100 \mathrm{~g}$ sample to $12.88 \mathrm{mg} \mathrm{N} / 100 \mathrm{~g}$ sample. As for sampling at 16:00 to 17:00 hours ranged from $17.92 \mathrm{mg} \mathrm{N} / 100 \mathrm{~g}$ samples up to $20.72 \mathrm{mg} \mathrm{N} / 100 \mathrm{~g}$ sample. The average value of $\mathrm{pH}$ at 06:00 to 07:00 hours the same sample at 5.3. Hours 12:00 to 13:00 ranged from 5.4 to 5.6, while the hours of 16:00 to 17:00 ranged from 5.5 to 5.6. The average value of the currency organoleptic ranged from 7.6 to 7.8 on the sampling clock 6:00 a.m. to 7:00, at 12:00 to 13:00 hours ranged from 7.0 to $7.3,4: 00$ p.m. to $17: 00$ hours ranged from 6.7 to 6,8 . The average value of organoleptic in the gills at 6:00 to $07: 00$ hour sampling ranged from 7.9 to 8.1 , clock 12:00 to 13:00 ranged from 7.6 to 7.7 , range antara7,2 4:00p.m. to 17:00 Hours - 7.4 . The average value of the meat organoleptic sampling 6:00 to $07: 00$ hours ranged from 7.9 to $8.1,12: 00$ to $13: 00$ hours ranged from 7.5 to 7.6 , clock 16:0017:00 ranged between 7.1 to 7,3 . The average value organoleptic texture sampling ranged from 6:00 to 7:00 hours to 8.0 to $8.4,12: 00$ to $13: 00$ hours ranged from 7.2 to 7.3, 16:00 to 17:00 hours ranged from 6.7 to 6,8 . Based on the research results of TVB-N value test, test and test the $\mathrm{pH}$ value value Appearance Tuna ( Thunnus albacares ) in Bersehati market is still suitable for consumption.
\end{abstract}

Keywords: $\quad$ Tuna, Thunnus albacares, quality assessment, TVB- $N$, $p H$, appearance, freshness.

\section{PENDAHULUAN}

Kemunduran mutu ikan disebabkan oleh aksi enzimatis dan aksi bakteri. Kedua aksi ini menguraikan komponen penyusun jaringan tubuh ikan sehingga menghasilkan perubahan fisik seperti daging ikan menjadi lunak dan perubahan kimia yang menghasilkan senyawa mudah menguap dan berbau busuk (Hadiwiyoto, 1993). Senyawa yang mudah menguap ini memberi kesan daging ikan telah menjadi busuk. Oleh karena itu, kadar senyawasenyawa ini dipakai sebagai indeks kemunduran mutu ikan. Kadar senyawa menguap ini dapat ditentukan secara laboratoris yang disebut dengan "penentuan kadar TVB-N" (Suwetja, 1993). Penentuan kadar TVB-N merupakan metode uji kesegaran bakteriologis yang berkaitan dengan pengujian organoleptik dan penentuan $\mathrm{pH}$. Semakin besar nilai kadar TVB$\mathrm{N}$ maka semakin tinggi pula nilai $\mathrm{pH}$-nya. Ini berbanding terbalik dengan penentuan organoleptik yang semakin kecil derajat penerimaannya oleh panelis. Penelitian ini bertujuan untuk mengetahui mutu ikan Tuna (Thunnus albacares) segar yang ada di pasar Bersehati dengan pengujian TVB-N, $\mathrm{pH}$ dan uji organoleptik dengan waktu pengambilan sampel dan pedagang yang berbeda.

\section{METODOLOGI PENELITIAN}

Sampel ikan Tuna segar dibeli di pasar Bersehati Kecamatan Wenang Kota Manado. Pengukuran mutu ikan Tuna segar dilaksanakan di laboratorium Kimia Hasil Perikanan, Fakultas Perikanan dan Ilmu Kelautan Universitas Sam Ratulangi Manado.

Alat-alat yang digunakan pada penelitian ini antara lain: cool box, termometer, score sheet organoleptik, timbangan analitik, nampan, pisau, tissue. Alat-alat yang digunakan untuk pengukuran $\mathrm{pH}$ yaitu mortar, $\mathrm{pH}$-meter, homogenizer, gelas kimia dan $\mathrm{pH}$ indikator universal, kertas label. Alat-alat yang digunakan untuk analisis TVB, yaitu kertas whatman, cawan Conway, mortar, pipet, inkubator, magnetic stirrer dan mikro buret, gelas kimia, pipet tetes, corong kaca, spatula, dan kertas label. Alat-alat yang digunakan untuk uji organoleptik pulpen, score sheet.

Bahan yang digunakan dalam penelitian ini antara lain: ikan Tuna dengan berat sekitar 1 $\mathrm{kg} / \mathrm{ekor}$, dan es. Bahan yang digunakan untuk 
analisis TVB, yaitu TCA (Trikhloroacetic Acid) $7 \%$, larutan Kalium karbonat $\left(\mathrm{K}_{2} \mathrm{CO}_{3}\right)$ jenuh, TCA 7,5\%, Larutan Indikator (methyl red dan bromo cresol green), Asam borat $\left(\mathrm{H}_{3} \mathrm{BO}_{3}\right)$, Asam klorida (HCL 0,02 N), vaselin. Bahan yang digunakan untuk pengukuran nilai $\mathrm{pH}$ adalah larutan buffer $\mathrm{pH} 7$, akuades dan kertas lakmus.

Metode penelitian yang digunakan adalah metode eksploratif deskriptif, yaitu mengumpulkan data fakta yang telah tersedia di lapangan melalui pencatatan dan pengamatan secara terperinci dan sistematik kemudian dilakukan analisa data berdasarkan data kualitatif dan data kuantitatif (Sudjana dan Kusuma, 2004).

Perlakuan yang diterapkan dalam penelitian ini dirancang sebagai berikut:

Perlakuan (A): waktu pengambilan sampel
$\mathrm{A}_{1}=$ Jam 06.00-07.00
$\mathrm{A}_{2}=$ Jam 11.00-12.00
$\mathrm{A}_{3}=$ Jam 16.00-17.00

Perlakuan (B): Pengambilan sampel dari 3 kelompok pedagang.

\section{$\mathrm{B}_{1}=$ Pedagang 1 \\ $\mathrm{B}_{2}=$ Pedagang 2 \\ $\mathrm{B}_{3}=$ Pedagang 3}

Ulangan yang digunakan dalam penelitian ini adalah sebanyak 3 kali. Tahap awal dalam melakukan penelitian ini adalah mempersiapkan bahan dan alat yang akan digunakan dalam penelitian tersebut. berikut:

Tata laksana penelitian adalah sebagai

1. Pengambilan hari pertama, dilakukan pengambilan sampel (ikan Tuna) pada jam 06.00-07.00, sebanyak 6 ekor untuk pedagang pertama, 6 ekor untuk pedagang kedua, dan 6 ekor untuk pedagang ketiga. Kemudian sampel dimasukkan ke dalam cool box dan diberi hancuran es dengan perbandingan 1:2 kemudian dibawa ke laboratorium untuk dilakukan analisa. Kemudian pada jam 11.00-12.00 dilakukan pengambilan sampel dan dilakukan penanganan sampel seperti yang pertama, selanjutnya pada jam 16.00-17.00 dilakukan pengambilan sampel yang ketiga dilakukan penanganan pada seperti pengambilan pertama dan kedua.

2. Pengambilan hari kedua, dilakukan pengambilan sampel pada jam 06.00-07.00, 11.00-12.00 dan 16.00-17.00 dengan jumlah dan cara penanganan seperti pengambilan pertama. Kemudian dibawa ke laboratorium untuk dilakukan analisa.
3. Pengambilan hari ke tiga, dilakukan pengambilan sampel pada jam 06.00-07.00 11.00-12.00 dan 16.00-17.00. Cara penanganan yang dilakukan sama dengan pengambilan sampel seperti hari pertama dan hari kedua. Kemudian dibawa ke laboratorium untuk dilakukan analisa.

Data yang diperoleh dibedakan menjadi 2 kategori yaitu data kualitatif dan kuantitatif. Data kualitatif dilakukan cukup dengan menghubungkan makna dari ke tiga data uji yang dilakukan. Data kuantitatif adalah data dalam bentuk bilangan, tabel-tabel dan grafik. Data untuk uji TVB-N, pH dan organoleptik yang diperoleh, dianalisa menggunakan rumus rataan.

\section{HASIL DAN PEMBAHASAN}

TVB merupakan salah satu metode penentuan kesegaran ikan yang dilakukan secara kimia. Prinsip penetapan TVB-N adalah menguapkan senyawa-senyawa Volatile yang terbentuk karena penguraian asam-asam amino yang terdapat pada daging ikan (Munandar, $d k k ., 2009)$.

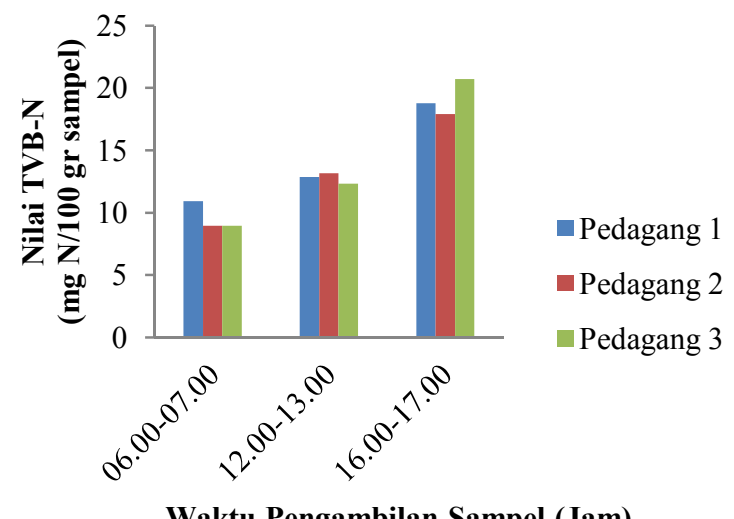

Gambar 1. Nilai rata-rata TVB-N ikan Tuna (T. albacares) segar pada pengambilan sampel, pedagang yang berbeda dan 3 kali ulangan.

Berdasarkan hasil penelitian diperoleh nilai rata-rata $\mathrm{TVB}-\mathrm{N}$ daging ikan Tuna segar yang dipasarkan di pasar Bersehati Manado dengan pengambilan sampel (06.00-07.00, $12.00-13.00, \quad 16.00-17.00)$ dan pedagang berbeda (pedagang 1,2 dan 3) (Gambar 1).

Nilai rata-rata TVB-N ikan Tuna yang terendah adalah $8,96 \mathrm{mg} \mathrm{N} / 100$ gr sampel pada pengambilan jam 06.00-07.00 sedangkan nilai rata-rata yang tertinggi adalah $10,92 \mathrm{mg} \mathrm{N} / 100$ gr sampel. Nilai rata-rata terendah pada pengambilan pada jam 12.00-13.00 adalah $12,32 \mathrm{mg} \mathrm{N} / 100$ gr sampel sedangkan nilai rata- 
rata TVB-N yang tertingginya adalah $13,16 \mathrm{mg}$ $\mathrm{N} / 100$ gr sampel. Nilai rata-rata TVB-N yang terendah pada jam 16.00-17.00 adalah 17,92 mg N/100 sedangkan nilai rata-rata TVB-N yang tertinggi adalah $20,72 \mathrm{mg} \mathrm{N} / 100 \mathrm{gr}$ sampel. Dengan melihat data TVB-N yang ada dapat dinyatakan bahwa ikan sampel pada pengambilan jam 06.00-07.00, 12.00-13.00, 16.00-17.00 pada ketiga kelompok pedagang masih layak dikonsumsi.

TVB-N digunakan sebagai batasan yang layak dikonsumsi. Nilai batas kesegaran bakterial hasil-hasil perikanan dengan uji kadar TVB-N oleh Suwetja (1993) ditetapkan sebesar $30 \mathrm{mg} \mathrm{N} / 100$ gr daging. Berdasarkan pernyataan tersebut maka pada pengambilan ikan Tuna jam 16.00-17.00 di pasar Bersehati Manado masih layak dikonsumsi dengan nilai rata-rata $18,76 \mathrm{mg} \mathrm{N} / 100 \mathrm{gr}$ ikan pada pedagang 1 , pada pedagang $2,17,92 \mathrm{mg} \mathrm{N} / 100$ gr ikan, dan pedagang $3,20,72 \mathrm{mg} \mathrm{N} / 100 \mathrm{gr}$ ikan.

Berdasarkan hasil penelitian, diperoleh nilai rata-rata $\mathrm{pH}$ ikan Tuna segar yang dipasarkan di pasar Bersehati Manado dengan waktu pengambilan sampel yang berbeda (06.00-07.00, 12.00-13.00, 16.00-17.00) dan pedagang berbeda (pedagang 1,2 dan 3) dapat dilihat pada Gambar 2 .

Nilai rata-rata $\mathrm{pH}$ ikan Tuna sampel pada jam 06.00-07.00 adalah sama yaitu 5,4. Nilai rata-rata $\mathrm{pH}$ yang terendah pada pengambilan jam 12.00-13.00 adalah 5,5 dan nilai rata-rata tertinggi adalah 5,6. Sedangkan pada sampel jam 16.00-17.00 nilai pH-nya adalah sama yaitu 5,6. Dengan melihat data $\mathrm{pH}$ yang ada dapat disimpulkan bahwa ikan sampel pada pengambilan jam 06.00-07.00, 12.00 13.00, 16.00-17.00 pada ketiga kelompok pedagang masih layak dikonsumsi.

Penetapan kemunduran mutu ikan secara subyektif (organoleptik) dapat dilakukan dengan menggunakan score sheet yang telah ditetapkan oleh Badan Standarisasi Nasional dengan SNI-2346-2006, meliputi penampakkan luar, kelenturan daging, keadaan mata, daging perut, serta warna insang.

Berdasarkan hasil penelitian, diperoleh nilai organoleptik mata ikan Tuna yang dipasarkan dengan pengambilan sampel yang berbeda $(06.00-07.00,12.00-13.00,16.00-$ 17.00) dan pedagang berbeda (pedagang 1, 2 dan 3) dapat dilihat pada Gambar 3.

Ikan yang mempunyai nilai organoleptik dengan kisaran 5-6 termasuk dalam kategori agak segar dan kisaran 7-9 termasuk kategori segar (SNI 01-2346-2006). Hasil penelitian diperoleh nilai rata-rata organoleptik mata ikan Tuna yang terendah adalah 7,6 sedangkan nilai rata-rata tertinggi adalah 7,8 pada pengambilan sampel jam 06.00-07.00. Nilai rata-rata organoleptik mata ikan tuna yang terendah adalah 7,1 sedangkan nilai rata-rata tertinggi adalah 7,3 pada pengambilan sampel jam 12.00-13.00. pada pengambilan sampel jam 16.00-17.00 nilai rata-rata organoleptik mata adalah sama yaitu 6,8 . Dengan melihat data organoleptik mata yang ada dapat dinyatakan bahwa ikan sampel pada pengambilan jam 06.00-07.00, 12.00-13.00, 16.00-17.00 pada ketiga kelompok pedagang masih layak dikonsumsi.

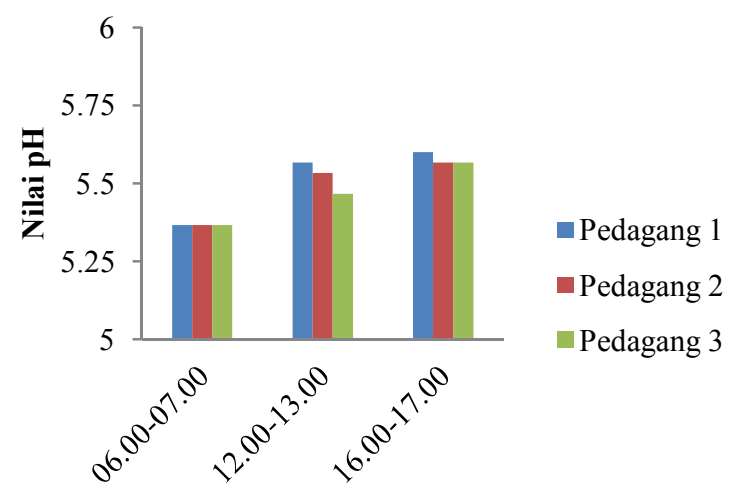

Waktu Pengambilan Sampel (Jam)

Gambar 2. Nilai rata-rata pH ikan Tuna ( $T$. albacares) segar pada waktu pengambilan sampel, pedagang yang berbeda dan 3 kali ulangan.

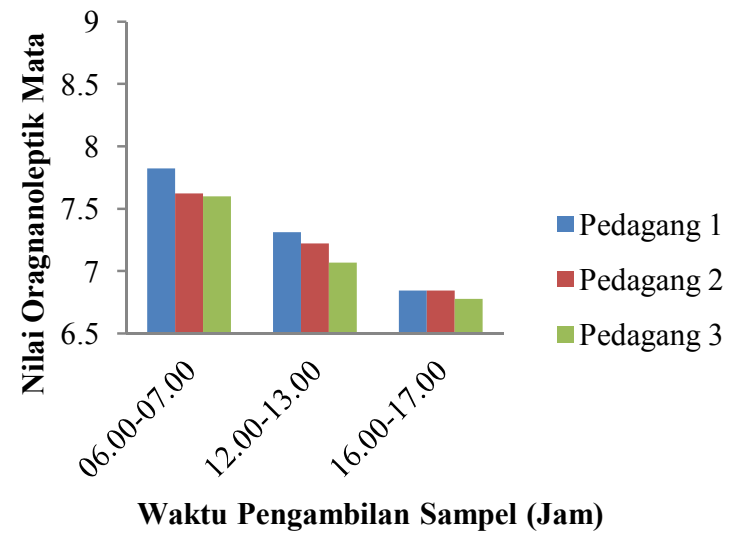

Gambar 3. Nilai rata-rata organoleptik mata ikan Tuna (Thunnus albacares) segar pada waktu pengambilan sampel, pedagang yang berbeda dan 3 kali ulangan.

Berdasarkan hasil penelitian, diperoleh nilai organoleptik insang ikan Tuna yang dipasarkan di pasar Bersehati Manado dengan pengambilan sampel yang berbeda (06.0007.00, 12.00-13.00, 16.00-17.00) dan pedagang 
berbeda (pedagang 1,2 dan 3) dapat dilihat pada Gambar 4.

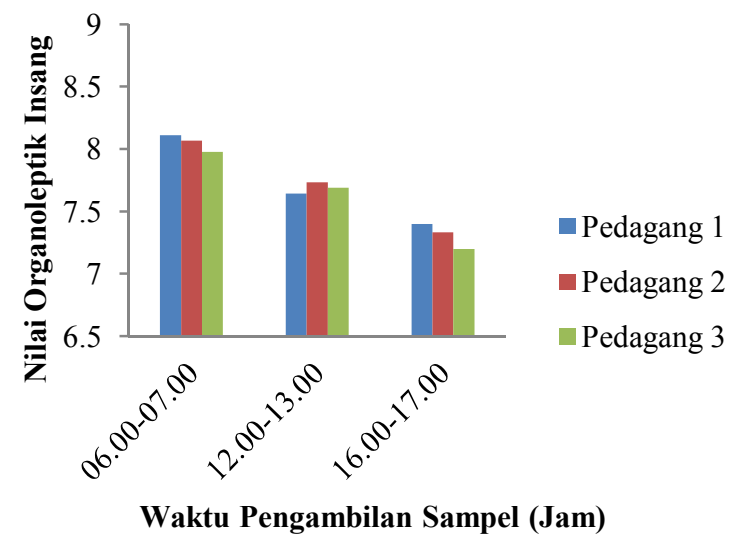

Gambar 4. Nilai rata-rata organoleptik insang ikan Tuna (Thunnus albacares) segar pada waktu pengambilan sampel, pedagang yang berbeda, dan 3 kali ulangan.

Ikan yang mempunyai nilai organoleptik dengan kisaran 5-6 termasuk kategori agak segar dan kisaran nilai organoleptik antara 7-9 termasuk kategori segar (SNI 01-2346-2006). Hasil penelitian diperoleh nilai rata-rata organoleptik insang ikan Tuna yang terendah adalah 7,9 sedangkan nilai rata-rata tertinggi adalah 8,1 pada pengambilan sampel jam 06.00-07.00. Nilai rata-rata organoleptik insang ikan Tuna yang terendah adalah 7,6 sedangkan nilai rata-rata tertinggi adalah 7,7 pada pengambilan sampel jam 12.00-13.00. Pada pengambilan sampel jam 16.00-17.00 nilai ratarata organoleptik insang terendah adalah 7,2 dan nilai rata-rata tertinggi adalah 7,4. Dengan melihat data organoleptik insang yang ada dapat dinyatakan bahwa ikan sampel pada pengambilan jam 06.00-07.00, 12.00-13.00, 16.00-17.00 pada ketiga kelompok pedagang masih layak dikonsumsi.

Berdasarkan hasil penelitian, diperoleh nilai organoleptik daging ikan Tuna yang dipasarkan di pasar Bersehati Manado dengan pengambilan sampel yang berbeda (06.00$07.00,12.00-13.00,16.00-17.00)$ dan pedagang berbeda (pedagang 1, 2 dan 3) dapat dilihat pada Gambar 5.

Ikan yang mempunyai nilai organoleptik dengan kisaran 5-6 termasuk kategori agak segar dan kisaran nilai organoleptik antara 7-9 termasuk kategori segar (SNI 01-2346-2006). Hasil penelitian diperoleh nilai rata-rata organoleptik daging ikan Tuna yang terendah adalah 7,9 sedangkan nilai rata-rata tertinggi adalah 8,1 pada pengambilan sampel jam 06.00-07.00. Nilai rata-rata organoleptik daging yang terendah adalah 7,5 sedangkan nilai rata-rata tertinggi adalah 7,6 pada pengambilan sampel jam 12.00-13.00. Pada pengambilan sampel jam 16.00-17.00 nilai ratarata organoleptik daging terendah adalah 7,2 dan nilai rata-rata tertinggi adalah 7,3. Dengan melihat data organoleptik daging yang ada dapat dinyatakan bahwa ikan sampel pada pengambilan jam 06.00-07.00, 12.00-13.00, 16.00-17.00 pada ketiga kelompok pedagang masih layak dikonsumsi.

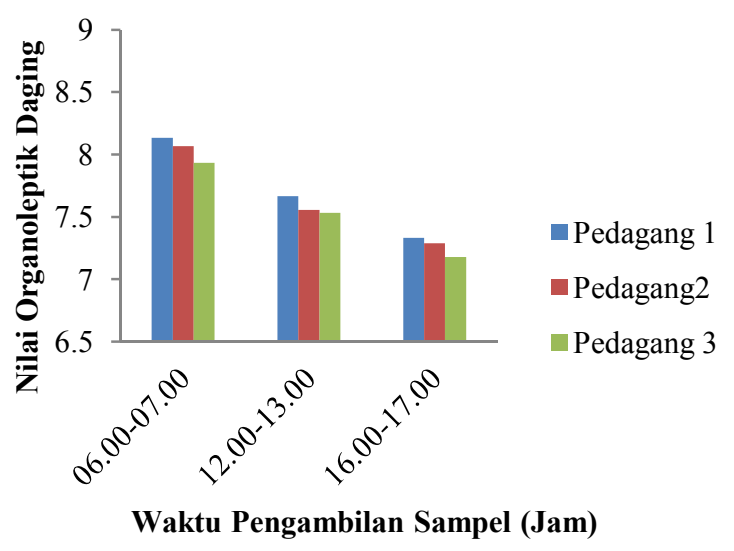

Gambar 5. Nilai rata-rata organoleptik daging ikan Tuna (Thunnus albacares) segar pada waktu pengambilan sampel, pedagang yang berbeda dan 3 kali ulangan.

Berdasarkan hasil penelitian, diperoleh nilai organoleptik tekstur ikan Tuna yang dipasarkan di pasar Bersehati Manado dengan pengambilan sampel yang berbeda (06.00$07.00,12.00-13.00,16.00-17.00)$ dan pedagang berbeda (pedagang 1, 2 dan 3) dapat dilihat pada Gambar 6.

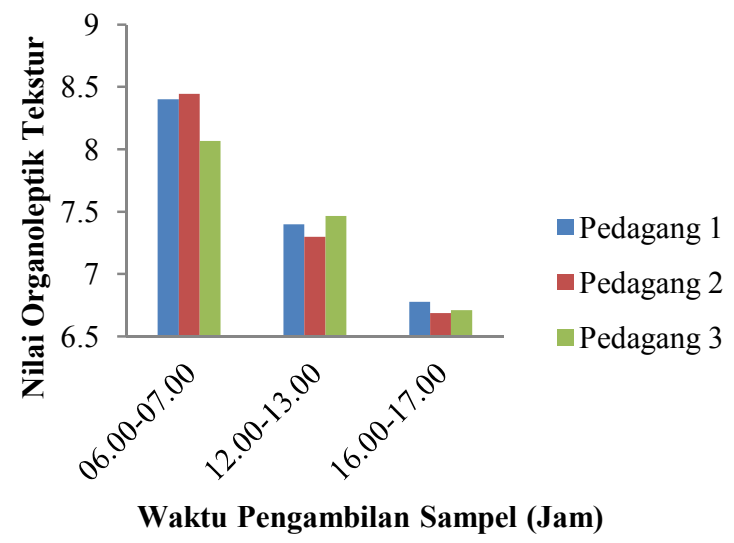

Gambar 6. Nilai rata-rata organoleptik tekstur ikan Tuna (Thunnus albacares) segar pada waktu pengambilan sampel, pedagang yang berbeda, dan 3 kali ulangan.

Ikan yang mempunyai nilai organoleptik dengan kisaran 5-6 termasuk kategori agak 
segar dan kisaran nilai organoleptik antara 7-9 termasuk kategori segar (SNI 01-2346-2006). Hasil penelitian diperoleh nilai rata-rata organoleptik tekstur ikan Tuna yang terendah adalah 8,0 sedangkan nilai rata-rata tertinggi adalah 8,4 pada pengambilan sampel jam 06.00-07.00. Nilai rata-rata organoleptik tekstur yang terendah adalah 7,3 sedangkan nilai rata-rata tertinggi adalah 7,5 pada pengambilan sampel jam 12.00-13.00. Pada pengambilan sampel jam 16.00-17.00 nilai ratarata organoleptik tekstur terendah adalah 6,7 dan nilai rata-rata tertingginya adalah 6,8 . Dengan melihat data organoleptik tekstur yang ada dapat dinyatakan bahwa ikan sampel pada pengambilan jam 06.00-07.00, 12.00-13.00, 16.00-17.00 pada ketiga kelompok pedagang masih layak dikonsumsi.

Dengan melihat data hasil nilai organoleptik, baik pada mata, insang, daging, dan tekstur ikan sampel dengan waktu pengambilan sampel jam 06.00-07.00, 12.00$13.00,16.00-17.00$ dan pedagang (pedagang 1,2 dan 3) dapat disimpulkan bahwa sampel masih layak dikonsumsi.

\section{KESIMPULAN}

Berdasarkan nilai TVB-N, ikan Tuna (Thunnus albacares) segar di pasar Bersehati Manado masih layak dikonsumsi sampai pada pengambilan sampel jam 16.00-17.00 dari ketiga pedagang, karena nilai batas kesegaran masih di bawah batas.

Berdasarkan nilai $\mathrm{pH}$, ikan Tuna $(T$. albacares) segar di pasar Bersehati Manado masih layak dikonsumsi sampai pada pengambilan sampel jam 16.00-17.00 dari ketiga pedagang, karena hal ini ditunjang oleh nilai $\mathrm{pH}$ yang masih di bawah nilai batas kesegaran.

Ikan Tuna (T. albacares) segar di pasar Bersehati Manado masih layak dikonsumsi sampai pada pengambilan sampel jam 16.0017.00 dari ketiga pedagang. Hal ini ditunjang oleh nilai organoleptik yang masih baik.

\section{DAFTAR PUSTAKA}

Hadiwiyoto, S. 1993. Teknologi Pengolahan Hasil Perikanan. Jilid 1. Penerbit Liberty. Jakarta.

Juniarto. 2003. Teknik Penanganan Ikan. Penebar Swadaya. Jakarta.

Munandar. Aris. Et, al. 2009. Kemunduran Mutu Ikan Nila (Oreochromis niloticus) Pada Penyimpanan Suhu Rendah dengan Perlakuan Cara Kematian dan Penyiangan. Institut Pertanian Bogor.

Sudjana, N dan A. Kusuma. 2004. Proposal Penelitian di Perguruan Tinggi. Sinar Baru Algensindo. Bandung

Suwetja, I.K., 1993. Metode Penentuan Mutu Ikan. Jilid I. Penentuan Kesegaran. Fakultas Perikanan dan Ilmu Kelautan Universitas Sam Ratulangi Manado. 